\title{
Asas Umum Pemerintahan Yang Baik Berlandaskan Pancasila Sebagai Dasar Penggunaan Diskresi
}

\author{
Muhammad Aziz Zaelani, I Gusti Ketut Ayu Rachmi Handayani, Isharyanto \\ Universitas Sebelas Maret Surakarta \\ Jln. Ir Sutarmi No. 36 A, Pucangsawit, Jebres, Surakarta \\ zael.aziz@gmail.com; ayu_igk@staff.uns.ac.id; isharyanto_fh@staff.uns.ac.id
}

Received: 10 September 2019; Accepted: 17 Desember 2019; Published: 17 Februari 2020

DOI: 10.20885 /iustum.vol26.iss3.art2

\begin{abstract}
This study aims to answer two problems: first, classifying and describing the antinomy of discretionary regulation in Law No. 30 of 2014 concerning Government Administration; and secondly, carrying out the construction on AUPB that has been filtered with Pancasila. Antinomy is the root of the conflict between freedom and responsibility. In this paper, antinomy is used as a way of thinking to examine the legality of limiting discretion. This is a doctrinal legal research. The sources information used in the study are primary legal materials (relevant regulations and documents) to be further analysed in a qualitative manner. Conceptual, historical and comparative law approaches are used to help solve problem formulations. The results showed that first, the antinomy that is governed under Law No. 30 of 2014 is irrelevant to the rule of law principles, thus creating confusion in the praxis realm of of the government; Second, the construction of a regulation is needed to formulate AUPB based on Pancasila as the basis for regulating discretion.
\end{abstract}

Keywords: Government administration; antimony, discretion; Pancasila

Abstrak

Penelitian ini bertujuan menjawab dua permasalahan, yaitu: pertama, mengklasifikasi dan menguraikan antinomi pengaturan diskresi dalam UU No. 30 Tahun 2014 Tentang Administrasi Pemerintahan, dan kedua, melakukan konstruksi terhadap AUPB yang telah difiltrasi dengan Pancasila. Antinomi merupakan puncak pertentangan kebebasan dengan tanggung jawab. Dalam tulisan ini, antinomi digunakan sebagai cara berpikir untuk mengetahui eksistensi legalitas pembatasan diskresi. Penelitian ini merupakan penelitian hukum doktrinal. Sumber informasi hukum menggunakan bahan hukum primer (peraturan dan dokumen relevan) untuk selanjutnya dilakukan analisis secara kualitatif. Pendekatan konseptual, historis, dan perbandingan hukum digunakan untuk membantu pemecahan rumusan masalah. Hasil penelitian menyimpulkan bahwa pertama, antinomi yang terdapat dalam UU No. 30 Tahun 2014 tidak relevan dengan prinsip negara hukum, menimbulkan kebingunggan di ranah praksis pemerintahan; Kedua, diperlukan konstruksi undang-undang untuk memformulasikan AUPB yang berlandaskan Pancasila sebagai dasar pengaturan diskresi.

Kata-kata Kunci: Administrasi pemerintahan; antinomy; diskresi; Pancasila 


\section{Pendahuluan}

Praktik welfare state menegaskan bahwa tindakan pemerintah pada asasnya harus berdasarkan asas legalitas. ${ }^{1}$ Namun, dalam hal-hal tertentu pemerintah dapat melakukan tindakan secara bebas (diskresi) didasarkan pada asas ermessen, yakni kewenangan yang sah untuk turut campur dalam kegiatan sosial guna melaksanakan tugas-tugas penyelenggaraan kepentingan umum. ${ }^{2}$ Hadirnya UU No. 30 Tahun 2014 tentang Administrasi Pemerintahan (UU AP) diharapkan dapat mengisi ruang kosong hukum administrasi termasuk penggunaan diskresi. Akan tetapi, undang-undang ini justru memasung penggunaan diskresi, sesuatu yang dipandang sebagai antinomi.

David Hume mendefinisikan bahwa antinomi akan selalu eksis/ada dalam suatu materi ataupun prinsip. ${ }^{3}$ Immanuel Kant mengkonsepsi antinomi sebagai dua hal yang saling bertentangan namun mempunyai sifat kausalitas dan harus tetap ada secara stimultan yang ditampung dalam suatu kaidah hukum. Hal ini disebut antinomi dalam kaidah hukum atau peraturan perundang-undangan. ${ }^{4}$ Antinomi dalam UU AP pada tulisan ini berpuncak secara konfliktual antara kebebasan pemerintah dalam melakukan fungsinya, dan tanggung jawab dalam pelaksanaan inisiasi tersebut untuk melindungi hak-hak warga negara. UU AP didasari oleh perubahan paradigma pelayanan publik, ${ }^{5}$ yang mengharuskan badan atau pejabat pemerintah lebih responsif terhadap masyarakat. Dinamika tersebut melahirkan paradigma baru yang mengutamakan pelayanan publik. Paradigma rule government menjadi good governance. ${ }^{6}$ Julista Mustamu mengemukakan, bahwa pemerintah harus melaksanakan pembatasan kegiatan pemerintah dalam hlm. 3 .

${ }^{1}$ Sjachran Basah, Eksistensi dan Tolok Ukur Badan Peradilan Administrasi di Indonesia, Alumni, Bandung, 1985 ,

2 Phillipus M. Hadjon, Hukum Administrasi dan Good Governance, Universitas Trisakti, Jakarta, 2010, hlm. 24.

3 Zainal A. Mochtar, "Antinomi dalam Peraturan Perundang-Undangan di Indonesia”, Hasanuddin Law Review, Vol. 1 No. 3, Desember 2015, hlm. 316-336.

${ }^{4}$ Wolfgang Friedmann, Teori dan Filsafat Hukum, Telaah Kritis Atas Teori-Teori Hukum, Rajawali Press, Jakarta, 1990, hlm. 35-45.

${ }^{5}$ Rusnan, "Konsep Negara Hukum Dalam Hubungan Kekuasaan Freiss Ermessen Dalam Welfare State", Jurnal IUS, Vol. 11 No. 4, April 2014, hlm. 1-10. hlm. 2.

${ }^{6}$ Sirajudin, Hukum Pelayanan Publik Berbasis Partisipasi Dan Keterbukaan Informasi, Setara Press, Malang, 2012, 
melakukan pelayanan publik ke masyarakat termasuk diskresi yang dibatasi. ${ }^{7}$ Berbeda pendapat, Krishna Djaya Darumurti menguatkan makna diskresi dengan mengetengahkan asas-asas hukum yang melandasi kekuasaan diskresi pemerintah dan asas-asas hukum yang membatasi penerapan diskresi pemerintah. ${ }^{8}$

Ketentuan UU AP mengedepankan unsur legalitas seperti dalam Pasal 26, 27, 28, dan 29 mengenai persetujuan atasan apabila penggunaan diskresi berpotensi merubah alokasi anggaran. Hal ini bertentangan dengan posisi ermessen sebagai asas yang berprinsip dari inisiasi pemerintah mendobrak kekakuan hukum untuk segera menyelesaikan persoalan mendesak dalam masyarakat. Hal selanjutnya, penulis mengkritisi AUPB dalam Pasal 10 UU AP yang harus disempurnakan dengan asas equity sebagai refleksi Pancasila guna meletakkannya sebagai ideologi hukum praktis. Inti penelitian ini adalah mengkonstruksikan dasar penggunaan diskresi dalam bentuk undang-undang yang berdiri sendiri dengan berpilar kepada AUPB yang telah difiltrasi dengan Pancasila sebagai ideologi hukum Indonesia. Tujuan akhir konstruksi tersebut diharapkan mampu menjadi dasar penggunaan diskresi yang sesuai dengan nilai Pancasila sebagai meta-norm hasil konkritisasi nilai-nilai (virtue) luhur bangsa ini.

\section{Rumusan Masalah}

Penelitian ini merumuskan dua permasalahan, yaitu pertama, bagaimana bentuk antinomi dalam UU No. 30 Tahun 2014 tentang Administrasi Pemerintahan? Kedua, bagaimana konstruksi ideal Asas Umum Pemerintahan Yang Baik untuk melaksanakan diskresi berlandaskan Pancasila?

\section{Tujuan Penelitian}

Penelitian ini bertujuan untuk pertama mengetahui dan menganalisis bentuk antinomi dalam UU No. 30 Tahun 2014 Tentang Administrasi Pemerintahan, dan kedua melakukan konstruksi ideal Asas Umum Pemerintahan Yang Baik untuk melaksanakan diskresi yang berlandaskan Pancasila.

${ }^{7}$ Julista Mustamu, "Diskresi Dan Tanggungjawab Administrasi Pemerintahan”, Jurnal Sasi, Vol. 17 No. 2 , April-Juni 2011, hlm. 1-9.

${ }^{8}$ Krishna D. Darumurti, Diskresi Kajian Teori Hukum, Genta Publishing, Yogyakarta, 2016, hlm. 23. 
Metode Penelitian

Penelitian hukum doktrinal ini menggunakan bahan hukum primer (UU No. 30 Tahun 2014 tentang Administrasi Pemerintahan) untuk dianalisis secara kualitatif dengan metode berpikir deduktif. Pendekatan konseptual dilakukan manakala peneliti tidak beranjak dari aturan hukum yang ada. Pendekatan konseptual perlu menggali prinsip-prinsip hukum yang dapat ditemukan dari pandangan sarjana ataupun doktrin hukum. ${ }^{9}$ Didukung dengan pendekatan komparatif untuk menjawab permasalahan.

\section{Hasil Penelitian dan Pembahasan}

Bentuk Antinomi Diskresi dalam Undang-Undang Nomor 30 Tahun 2014 tentang Administrasi Pemerintahan

Antinomi berkaitan dengan persetujuan Atasan Pejabat tentang penggunaan diskresi yang berpotensi mengubah alokasi anggaran. Penjelasan Pasal 25 UU AP berbunyi :

Ayat (1)

Yang dimaksud dengan memperoleh persetujuan dari "Atasan Pejabat" adalah memperoleh persetujuan dari atasan langsung pejabat yang berwenang menetapkan dan/atau melakukan Keputusan dan/atau Tindakan.

Bagi pimpinan satuan kerja perangkat daerah (SKPD) mengajukan persetujuan kepada kepala daerah.

Bagi Bupati/Walikota mengajukan persetujuan kepada gubernur.

Bagi gubernur mengajukan persetujuan kepada menteri yang menyelenggarakan urusan pemerintahan dalam negeri.

Bagi pimpinan unit kerja pada kementerian/lembaga mengajukan persetujuan kepada menteri/pimpinan lembaga.

Diskresi diejawantahkan dari ermessen (tindakan/bertindak), freies ermessen (kebebasan bertindak) yang melekat dalam diri pemerintah yang menjadi hak untuk melakukan inisiasi dengan batas-batas tertentu. Batasan ermessen lebih tepat menggunakan pendapat Sjahran Basah, yaitu berbentuk pertanggungjawaban yang memuat adanya batas-batas ketaatan akan asas atau disebut juga ketaatasasan, yaitu batas-atas dan batas-bawah. ${ }^{10}$ Antinomi berpuncak pada dua

\footnotetext{
${ }_{9}^{9}$ Peter M. Marzuki, Penelitian Hukum, Prenadamedia Group, Jakarta, 2005, hlm. 181. hlm. 3-5.

${ }^{10}$ Sjachran Basah, Perlindungan Hukum terbadap Sikap-Tindak. Administrasi Negara, Alumni, Bandung, 1992,
} 
hulu berbeda yaitu : pertama, Diskresi pada asasnya merupakan hak yang melekat dalam diri pemerintah karena berakar dari ermessen yakni kewenangan yang sah untuk turut campur dalam kegiatan sosial guna melaksanakan tugas-tugas penyelenggaraan kepentingan umum ${ }^{11}$; dan Kedua, diskresi bukan lagi hak yang melekat dalam diri pemerintah, terbatas dalam hal penggunaannya karena harus melalui validitas dari atasan pejabat terkait. Hal ini merintangi ermessen sebagai kaidah kebebasan bertindak.

Diskresi wajib memenuhi syarat, prosedur dan batasannya. Dalam Pasal 30 sampai dengan Pasal 32 UU AP, memberikan opsi bahwa penggunaan diskresi yang: pertama, melampaui wewenang, Kedua, mencampuradukkan wewenang, dan Ketiga, dikategorikan sebagai tindakan sewenang-wenang, maka penggunaan diskresi tersebut dapat dibatalkan atau tidak sah. Dapat dibatalkan, atau tidak sahnya diskresi ditentukan oleh pasal-pasal, termasuk AUPB dalam undang-undang tersebut yang telah dikonkretisasi sehingga cakupannya terbatas pada apa yang tertulis penjelasannya.

Indroharto berpendapat diskresi merupakan bentuk kebebasan untuk menentukan kebijaksanaan atau kebebasan untuk mengadakan suatu penilaian mana yang baik, kurang baik, dan penilaian mana yang tepat dan tidak tepat. Dalam implementasi diskresi, ditemukan dua pola, yaitu : pertama, kebebasan untuk menilai secara objektif, yaitu bilamana norma dalam undang-undangnya bersifat samar-samar akan tetapi sesungguhnya dimaksudkan sebagai norma hukum yang obyektif, karena rumusan eksplisitnya sulit untuk diberikan, misalnya: rumusan bertingkah laku sebagai abdi negara yang baik; dan, Kedua, kebebasan menilai secara subjektif, artinya adanya kebebasan melakukan suatu kebijakan sendiri, karena dalam hal ini undang-undang telah memberikan wewenang kepada pejabat publik untuk menentukan sendiri apa yang harus dilakukan ketika menghadapi suatu peristiwa atau permasalahan yang konkret. ${ }^{12}$

${ }^{11}$ Istilah Ermessen yang oleh beberapa penulis Indonesia diawali dengan kata sifat "freies" sesungguhnya tidak tepat. Philipus M. Hadjon mengatakan bahwa hukum administrasi Jerman "Ermessen" dan bukan "freies Ermessen." Lihat: Phillipus M. Hadjon, et.al., Hukum Administrasi dan Good Governance, Jakarta, Universitas Trisakti, 2010, hlm. 24.

${ }^{12}$ Indroharto, Peradilan Tata Usaha Negara, Pustaka Sinar Harapan, Jakarta, 1993, hlm. 98-99. 
Pengertian kebijaksanaan memerlukan pertimbangan lebih jauh lagi, sedangkan kebijakan mencakup aturan-aturan yang ada di dalamnya. ${ }^{13}$ Kebijakan yang telah memasuki bidang kehidupan hukum, maka perumusannya juga harus tunduk pada teknik pembuatan perundang-undangan yang akan dituangkan atau dinyatakan dalam bentuk peraturan harus memenuhi kriteria-kriteria tertentu. Cara perumusan yang dilakukan melalui peraturan perundang undangan adalah dengan membuat rumusan-rumusan hipotesis. ${ }^{14}$

Kebijakan tidak tercipta secara spontan, namun harus didahului dengan perencanaan matang. ${ }^{15}$ Sedangkan diskresi selalu spontan berakar dari ermessen yang menuntut inisiasi (menitikberatkan pada kebijaksanaan) pemerintah dalam menyelesaikan permasalahan mendesak masyarakat. Penulis berasumsi, diskresi baru muncul bilamana kebijakan tidak berjalan dengan baik dalam ranah praktek. Diskresi hakikatnya menampakkan suatu kecenderungan berupa pengecualian dari keharusan bertindak sesuai aturan umum (general rule) dari peraturan perundang-undangan (pendekatan rule-based atau rule following). ${ }^{16}$ Tataran doktrin menyimpulkan pada asasnya, tidak bisa menguji suatu kewenangan bebas, selama kewenangan bebas tersebut dalam penggunaannya tidak: pertama, bertentangan dengan kepentingan umum; Kedua, menimbulkan konflik kepentingan; dan, Ketiga, tidak menerabas atau melanggar kuasa perjanjian perdata. ${ }^{17}$

Konklusinya, diskresi tidak cukup diuji secara wetmatigheid, namun harus diuji secara doelmatigheid dengan batu uji AUPB. Permasalahannya, AUPB dalam Pasal 10 UU AP merupakan konkretisasi asas ke bentuk norma hukum tertulis. Oleh karena itu, pemaknaan terhadap asas kepastian hukum; ${ }^{18}$ asas kemanfaatan;19

${ }^{13}$ I Wayan Suandi, "Eksistensi Kebijakan Publik Dan Dalam Penyekenggaraan Pemerintahan Daerah”, Jurnal Ilmiah Fisip, Vol. 1 No. 1, 2010, hlm. 12-13.

${ }^{14}$ Satjipto Rahardjo, Ilmu Hukum, Alumni, Bandung, 1986, hlm. 71.

15 Irfan Islamy, Prinsip-Prinsip Perumusan Kebijakan Negara, Bina Aksara, Jakarta, 2004, hlm. 78.

${ }^{16}$ Krishna D. Darumurti, Op. Cit., hlm. 24.

${ }_{17}$ Bagir Manan, B, Konvensi Ketatanegaraan, CV Armico, Bandung, 1987, hlm. 73.

18 Asas kepastian hukum dalam UU AP adalah asas dalam negara hukum yang mengutamakan landasan ketentuan peraturan perundang-undangan, kepatutan, keajegan, dan keadilan dalam setiap kebijakan penyelenggaraan pemerintahan.

19 Asas kemanfaatan dalam UU AP adalah manfaat yang harus diperhatikan secara seimbang antara : (1) kepentingan individu yang satu dengan kepentingan individu yang lain; (2) kepentingan individu dengan masyarakat; (3) kepentingan Warga Masyarakat dengan masyarakat asing; (4) kepentingan kelompok masyarakat yang satu dan kepentingan kelompok masyarakat yang lain; (5) kepentingan pemerintah dengan Warga Masyarakat; (6) kepentingan generasi yang sekarang dan kepentingan generasi mendatang; (7) kepentingan manusia dan ekosistemnya; (8) kepentingan pria dan wanita. 
asas ketidakberpihakan;20 asas kecermatan ${ }^{21}$; asas tidak menyalahgunakan kewenangan ${ }^{22}$; asas keterbukaan ${ }^{23}$; asas kepentingan umum ${ }^{24}$; dan asas pelayanan yang baik ${ }^{25}$, telah dikunci secara normatif pemaknaannya seperti dalam Penjelasan Pasal 10 UU AP. Oleh karenanya, perlu dikonstruksikan AUPB dengan cakupan lebih luas yang berlandaskan Pancasila sebagai dasar penggunaan dan pengujian diskresi.

Ketentuan UU AP menyangkut Peradilan Tata Usaha Negara (PTUN) tidak didasarkan atas pendekatan konseptual yang jelas, sehingga menyulitkan penerapannya dalam praktek peradilan karena di samping konsep yang tidak jelas juga bertentangan dengan konsep-konsep hukum administrasi di Indonesia. ${ }^{26} \mathrm{Hal}$ ini dikarenakan beberapa sebab seperti kurangnya sosialisasi atau bahkan keengganan hakim untuk menambah pengetahuannya, kengganan hakim untuk memulai sesuatu yang baru atau sebab-sebab lainnya. ${ }^{27}$

Kebingungan dalam ranah praktis, mendorong dikeluarkannya Instruksi Presiden :

Instruksi Presiden Republik Indonesia Nomor 1 Tahun 2016, tanggal 9 Januari 2016, Tentang Percepatan Pelaksanaan Proyek Strategi Nasional, Presiden RI menginstruksikan kepada: (1) para Menteri Kabinet Kerja; (2) Jaksa Agung R.I; (3) Kapolri R.I; (4) Sekretaris Kabinet; (5) Kepala Staf Presiden; (6) Para Kepala Lembaga Non Kementerian; (7) Para Gubernur; (8) Para Bupati/Walikota,

20 Asas ketidakberpihakan dalam UU AP adalah asas yang mewajibkan Badan dan/atau Pejabat Pemerintahan dalam menetapkan dan/atau melakukan Keputusan dan/atau Tindakan dengan mempertimbangkan kepentingan para pihak secara keseluruhan dan tidak diskriminatif.

${ }^{21}$ Asas kecermatan dalam UU AP adalah asas yang mengandung arti bahwa suatu Keputusan dan/atau Tindakan harus didasarkan pada informasi dan dokumen yang lengkap untuk mendukung legalitas penetapan dan./atau pelaksanaan Keputusan dan/atau Tindakan sehingga Keputusan dan/atau Tindakan yang bersangkutan dipersiapkan dengan cermat sebelum Keputusan dan/atau Tindakan tersebut ditetapkan dan/atau dilakukan.

22 Asas tidak menyalahgunakan kewenangan dalam UU AP adalah asas yang mewajibkan setiap Badan dan/atau Pejabat Pemerintahan tidak menggunakan kewenangannya untuk kepentingan pribadi atau kepentingan yang lain dan tidak sesuai dengan tujuan pemberian kewenangan tersebut, tidak melampaui, tidak menyalahgunakan, dan/atau tidak mencampuradukkan kewenangan.

${ }^{23}$ Asas keterbukaan dalam UU AP adalah asas yang melayani masyarakat untuk mendapatkan akses dan memperoleh informasi yang benar, jujur, dan tidak diskriminatif dalam penyelenggaraan pemerintahan dengan tetap memperhatikan perlindungan atas hak asasi pribadi, golongan, dan rahasia negara.

24 Asas kepentingan umum dalam AP adalah asas yang mendahulukan kesejahteraan dan kemanfaatan umum dengan cara yang aspiratif, akomodatif, selektif, dan tidak diskriminatif.

${ }^{25}$ Asas pelayanan yang baik dalam UU AP adalah asas yang memberikan pelayanan yang tepat waktu, prosedur dan biaya yang jelas, sesuai dengan standar pelayanan, dan ketentuan peraturan perundang-undangan.

${ }^{26}$ Philipus M. Hadjon, "Peradilan Tata Usaha Negara Dalam Konteks Undang-Undang No. 30 Tahun 2014 Tentang Administrasi pemerintahan”, Jurnal Hukum Dan Peradilan, Vol. 4 No. 1, Maret 2015, hlm. 51-64.

27 Tri Cahya I. Permana, "Peradilan Tata Usaha Negara Pasca Undang-Undang Administrasi Pemerintahan Ditinjau Dari Segi Access To Justice", Jurnal Hukum dan Peradilan, Vol .4 No. 3, November 2015, hlm. 419-442. 
untuk memberikan dukungan percepatan pelaksanaan Proyek Strategis Nasional dengan bentuk antara lainnya: a. meningkatkan tata kelola (governance) dan meningkatkan fungsi Aparat Pengawasan Intern Pemerintah dalam rangka pengawasan pembinaan Proyek Strategis Nasional; $b$. Mendahulukan proses administrasi pemerintahan dalam melakukan pemeriksaan dan penyelesaian atas laporan penyalahgunaan wewenang dalam pelaksanaan Proyek Strategis Nasional; c. Jaksa Agung R.I mendahulukan proses administrasi pemerintahan sesuai ketentuan UU Nomor 30 Tahun 2014 tentang Administrasi Pemerintahan sebelum melakukan penyidikan atas laporan masyarakat yang menyangkut penyalahgunaan wewenang dalam pelaksanaan Proyek Strategis Nasional.

Instruksi ditujukan kepada aparat penegak hukum agar jangan mengkriminalisasikan diskresi. Pemerintah mencatat banyaknya pejabat yang dipidana karena kasus korupsi diantaranya 8 Menteri, 19 Gubernur, 2 Gubernur Bank Indonesia, 5 Deputi Gubernur Indonesia, 40 Anggota DPR RI, 150 Anggota DPRD, dan sekitar 200 Bupati/Walikota. ${ }^{28}$ Data tersebut, menurut Presiden membawa implikasi ketakutan pejabat dalam mengambil keputusan dan/atau tindakan karena ketidakjelasan definisi korupsi serta maraknya kriminalisasi kebijakan dan prosedur administrasi pemerintahan yang kurang jelas dan transparan, akibatnya biaya yang harus ditanggung pemerintah sangat besar, yaitu lambatnya pembangunan akibat aparat negara takut mengambil keputusan. Belanja modal pemerintah baru mencapai 20 persen dari APBN dan dana daerah mengendap di bank sebesar 283 triliun. Untuk mengatasi hal tersebut, Presiden menilai penting kiranya menggunakan diskresi untuk mempercepat pelaksanaan pembangunan. ${ }^{29}$

Kebingungan menggunakan diskresi dalam ranah praktik membuat aparatur pemerintah khususnya yang berasal dari lingkup jalur karier enggan menggunakannya. ${ }^{30}$ Penyalahgunaan wewenang menjadi titik ketakutan pejabat yang berwenang menggunakan diskresi bilamana diabsorsi ke ranah pidana. ${ }^{31}$

28 Sumber : Republika, Jokowi Minta Kebijakan Jangan Dipidana, selengkapnya dapat dilihat di http://m.republika.co.id/berita/koran/halaman-1/15/08/25/ntmkg612-jokowi-minta-kebijakan jangandipidana, diakses pada hari Sabtu, tanggal 3 Agustus 2018.

${ }^{29}$ Ibid,

30 “KPK : Pejabat Jangan Takut Terbitkan Diskresi” https://m.cnnindonesia.com, diakses Kamis 29 Agustus 2019 pukul 19.00 WIB.

31 Pasal 3 UU No. 31 Tahun 1999 tentang Pemberantasan Tindak Pidana Korupsi jo perubahannya dalam UU No. 20 Tahun 2001 mendefinisikan penyalahgunaan wewenang secara ambigu dan sebatas delik formil saja. 
Terjadi ambiguitas karena menyalahgunakan wewenang tidak ditemukan eksplisitasnya dalam hukum pidana, maka hukum pidana dapat mempergunakan pengertian dan kata yang sama yang terdapat atau berasal dari cabang hukum lainnya. ${ }^{32}$

Eko Prasojo menjelaskan, di Jerman undang-undang yang mengatur tata cara pembuatan keputusan dan tindakan pejabat administrasi pemerintahan disebut dengan Undang-Undang Prosedur Administrasi atau Verwaltungsverfahrengesetz. ${ }^{33}$ Jerman mempunyai mekanisme dalam mengatur pembuatan keputusan dan tindakan pejabat publiknya. UU Administrasi Jerman merupakan model yang paling dekat dengan kajian sistematis model pengundangan administrasi pemerintahan Indonesia dicermati dari RUU Administrasi Pemerintahan ${ }^{34}$ (yang saat ini telah menjadi UU AP).

Jerman memberikan imunitas bagi para pejabat administrasi dalam menjalankan tugasnya, ditujukan untuk melindungi pejabat administrasi dari berbagai bentuk intervensi di luar sistem birokrasi pemerintah. Administrasi pemerintah di Jerman ditempatkan sebagai pilar keempat di samping eksekutif, legislatif dan yudikatif, mengingat urgensinya. ${ }^{35}$ Jelas UU Administrasi Jerman memberikan bentuk imunitas ${ }^{36}$ kepada pejabat pemerintah, berbeda dengan UU AP di Indonesia yang hanya berkutat kepada kewenangan administratif tanpa diikuti bentuk perlindungan hukum terhadap subyeknya.

Perlu dipahami kebebasan inisiasi/bertindak (ermessen) di Jerman tidak bebas (freies) sepenuhnya, karena terdapat pembatasan berupa prosedur, syarat serta akibat hukum dalam penggunaannya. Sjachran Basah memberikan pengertian freis Ermessen sebagai "keleluasaan dalam menentukan kebijakan-kebijakan melalui

\footnotetext{
32 Putusan Mahkamah Agung Nomor 977 K/PID/2004.

${ }_{33}$ M. Ikbar Andi Endang, "Diskresi Dan Tanggungjawab Pejabat Pemerintahan Menurut Undang-Undang Administrasi Pemerintahan”, Jurnal Hukum Peratun, Vol. 1 No. 2, Agustus 2018, hlm. 223-244.

34 Eko Prasojo, "Rancangan) Undang-Undang Administrasi Pemerintahan untuk Pembangunan Hukum Administrasi Negara dan Penciptaan Good Governance," disampaikan pada Bimbingan Teknis Hakim PTUN, Jakarta, 2011, hlm. 2.

${ }^{35}$ M. Ikbar Andi Endang, Op. Cit., hlm. 223-244.

36 Bentuk imunitas berupa perlindungan hukum terhadap administratur negara sehingga kesalahan terhadap perbuatan pemerintah diselesaikan melalui mekanisme peradilan administrasi tidak begitu saja diabsorsi ke ranah hukum lain.
} 
sikap/tindak administrasi negara yang harus dapat dipertanggungjawabkan". ${ }^{37}$ Antinomi ini menitikberatkan perbedaan kaidah administrasi negara, sehingga tidak asal melakukan adopsi terhadap produk hukum asing, yang jelas ini merupakan efek simulacra. ${ }^{38}$ Simulacra adalah kecenderungan melakukan injeksi unsur dari sistem hukum asing ke dalam sistem hukum asli negara sendiri. Hal ini didorong stigma menganggap pengaruh hukum asing lebih baik dan kompleks dalam menyelesaikan permasalahan. ${ }^{39}$

\section{Konstruksi Ideal Asas Umum Pemerintahan yang Baik untuk Melaksanakan Diskresi yang Berlandaskan Pancasila}

Antinomi dalam UU AP membuat rancu pelaksanaannya, tidak relevan dengan prinsip negara hukum. Rechtsstaat memberikan penekanan pada penerapan hukum sesuai dengan aturan yang terdapat dalam undang-undang. ${ }^{40}$ Pengaturan diskresi dalam UU No. 30 Tahun 2014, identik dengan UndangUndang tentang Prosedur Administrasi Jerman (Verwaltungsverfahrengesetz), dalam hal memuat prosedur (Pasal 26, 27, 28, 29), syarat (Pasal 24 dan 25), akibat hukum (Pasal 30, 31, 33), secara normatif merujuk pemenuhan legalitas dalam menggunakan diskresi. Hal tersebut perlu dipikirkan relevansinya dalam sistem hukum Indonesia yang dikawal oleh Pancasila sebagai ideologi hukumnya. Suatu falsafah bangsa identik dengan keinginan, watak dari bangsanya. Tidak mungkin mengambil falsafah negara lain untuk dijadikan falsafah bangsanya begitu saja karena segala aspek kehidupan bangsa harus sesuai dengan falsafahnya. ${ }^{41}$ Savigny, mengkonstruksikan teori tentang adanya hubungan organik antara hukum dengan watak atau karakter bangsa. Hukum sejati itu tidak dibuat namun harus ditemukan dalam jiwa rakyat/bangsa (volkgeist). Persoalan pengelolaan terhadap hukum bukan membentuk asas dan doktrin secara artifisial, namun menemukan asas dan doktrin dalam nilai-nilai hukum yang hidup dengan jalan menyelami inti jiwa dari

37 Istilah Ermessen yang oleh beberapa penulis Indonesia diawali dengan kata sifat "freies" sesungguhnya tidak tepat. Philipus M. Hadjon mengatakan bahwa hukum administrasi Jerman "Ermessen" dan bukan "freies Ermessen." Lihat: Phillipus M. Hadjon, et.al., Op. Cit

38 Anthon F. Susanto, Penelitian Hukum Transformatif-Partisipatoris, Setara Press, Malang, 2015, hlm. 321.

${ }^{39}$ Ibid., hlm. 321-322. hlm. 19.

40 Syarief Mappiasse, Logika Hukum Pertimbangan Putusan Hakim, Predana Media Group, Jakarta, 2015,

${ }^{41}$ Ni'matul Huda, Hukum Tata Negara Indonesia, Rajawali Press, Jakarta, 2005, hlm. 78. 
rakyat. ${ }^{42}$ Teori Savigny mendasari untuk ditemukannya konsep Diskresi yang sesuai dengan falsafah, watak atau karakter bangsa Indonesia, yaitu Diskresi yang berlandaskan Pancasila. Hal ini relevan karena Pancasila merupakan konkretisasi nilai luhur bangsa Indonesia.

Paradigma tujuan hukum didasari oleh doktrin bahwa hukum harus mencerminkan nilai dasar hukum, ${ }^{43}$ maka kepastian hukum menjadi ciri utama yang harus diselaraskan. Langkah relevan adalah dengan mencabut seluruh pasal yang mengatur diskresi dalam UU AP. Selama UU AP masih mengatur diskresi maka kebingunggan dalam ranah praktis terus terjadi, menyebabkan ketidakpastian hukum. Langkah berikutnya, membangun undang-undang tersendiri yang secara khusus mengatur diskresi. Konstruksi dilakukan dengan meletakkan AUPB yang berafiliasi dengan Pancasila sebagai dasar penggunaan diskresi dalam undang-undang tersebut.

Konstruksi dengan jalan membangun undang-undang tersendiri sebagai dasar penggunaan diskresi, terlebih dahulu harus menentukan nyawa undangundangnya. Hemat penulis mengenai perlunya konstruksi AUPB adalah :

1. AUPB yang diadopsi dalam norma tertulis tersebar dalam 7 peraturan perundang-undangan, perlu harmonisasi;

2. Diskresi, memerlukan AUPB tersendiri dalam satu bangunan undangundang, mengingat penggunaan diskresi adalah situasional, opsional dan merupakan langkah terakhir maka pengujian terhadapnya dilakukan secara wetmatiegheid dan doelmatiegheid;

3. AUPB yang baru berlandaskan Pancasila sebagai legal ideology, diharapkan dapat menciptakan penggunaan diskresi bernilai moral dan keadilan sosial.

AUPB yang telah difiltrasi atau disaring terlebih dahulu menggunakan Pancasila menjadi pilar dari undang-undang diskresi tersebut. Filtrasi menekankan satu proses pemisahan yang dapat dibedakan menjadi beberapa jenis tergantung pada bahan yang akan dipisahkan serta tingkat pemisahan yang diinginkan. ${ }^{44}$

42 Bernard L. Tanya dkk, Teori Hukum Strategi Tertib Manusia Lintas Ruang Dan Generasi, Genta Publishing, Yogyakarta, 2010, hlm. 103-104.

43 Achmad Ali, Menguak Tabir Hukum, Chandra Pratama, Jakarta, 1996, hlm. 85.

${ }^{44}$ Jajang Juansah dkk, "Peningkatan Mutu sari Buah Nanas Dengan Memanfaatkan Sistem Filtrasi Aliran Dead-End Dari Membran Selulosa Asetat," Makara Sains, Vol. 13 No. 1, April 2009, hlm. 94-100. 
Pancasila wajib masuk dan mengilhami seluruh aturan hukum di negara ini, oleh karenanya disebut sebagai ideologi hukum (legal ideology). Cotterrell memaknai ideologi sebagai gagasan yang mempengaruhi tindakan atau perilaku. "Legal ideology can be thought of, then, not as legal doctrin itself but as forms of social consciousness-system's of values and cognitive assumption-reflected in and expressed through legal doctrine." 45

Pancasila harus dituangkan terhadap obyek nyata atau konkret, yaitu menggunakan Pembukaan UUD NRI Tahun 1945 sebagai media filtrasi. Pembukaan UUD 1945 tidak terpisahkan dari batang tubuhnya dikarenakan ditempatkan sebagai pokok kaidah fundamental negara atau Staatsfundamentalnorm. Kedudukannya : Pertama, di atas Undang-Undang Dasar; Kedua, terpilah dengan Undang-Undang Dasar; dan, Ketiga, merupakan satu rangkaian dengan Undang-Undang Dasar. ${ }^{46}$

Ketut Rinjin, menyatakan Pancasila sebagai dasar negara Indonesia memiliki tiga pengertian dan tiga tingkatan, yaitu :

(i) sebagai dasar negara yang bersifat abstrak-universal seperti tercantum dalam Pembukaan UUD RI 1945; (ii) sebagai pedoman penyelenggaraan negara yang bersifat umum kolektif seperti tercantum pada Batang Tubuh UUD RI 1945; dan, (iii) sebagai petunjuk kebijakan penyelenggaraan negara yang bersifat khusus-konkrit seperti terdapat pada undang-undang, peraturan pemerintah, peraturan presiden, dan sebagainya. ${ }^{47}$

Berakar dari pertimbangan tersebut, penulis menggunakan Pancasila sebagai sarana filtrasi yang dilakukan dengan media Pembukaan UUD NRI Tahun 1945. Didasari muatan Pembukaan UUD NRI Tahun 1945 yang : Pertama, memiliki kekuatan mengikat secara hukum; Kedua, terkait dengan struktur kekuasaan secara formal; Ketiga, meliputi suasana kebatinan atau cita-cita hukum yang menguasai hukum dasar negara. Suasana kebatinan atau cita-cita hukum tersebut terangkum dalam empat pemikiran Pembukaan konstitusi. ${ }^{48}$

\footnotetext{
${ }^{45}$ Cotterrell, Roger, The Sociology OfLaw : An Introduction, Butterworths / Oxford University Press, London, 1992, hlm. 110 $40-41$.

${ }^{46}$ Joko Siswanto, Pancasila Refleksi Komperhensif Hal-Ihwal Pancasila, Ladang Kata, Yogyakarta, 2015, hlm.

${ }^{47}$ Winarno Pendidikan Pancasila di Perguruan Tinggi (Panduan Praktis Pembelajaran), Yuma Pustaka, Surakarta, 2012, hlm. 61.

${ }^{48}$ Joko Siswanto, Op. Cit., hlm. 39-40.
} 
Penulis menggunakan AUPB yang eksis dalam tujuh peraturan perundangundangan sebagai sarana pembanding, yaitu : Pertama, UU No. 5 Tahun 1986 tentang Peradilan Tata Usaha Negara sebagaimana diubah oleh UU No. 9 Tahun 2004 tentang Perubahan Atas UU Nomor 5 Tahun 1986 tentang Peradilan Tata Usaha Negara dan kembali diubah oleh UU No. Tahun 2009 tidak menyebutkan secara eksplisit asas yang digunakan. Dalam UU No. 5 Tahun 1986 penggunaan AUPB merujuk kepada doktrin dan juklak MA. Dalam UU No. 9 Tahun 2004 penggunaan AUPB merujuk kepada UU No. 28 Tahun 1999); Kedua, UU No. 28 Tahun 1999 tentang Penyelenggaraan Negara yang Bersih dan Bebas dari Korupsi, Kolusi, dan Nepotisme (terdapat tujuh asas yaitu : Asas Kepastian Hukum; Asas Tertib Penyelenggaraan Negara; Asas Kepentingan Umum; Asas Keterbukaan; Asas Proporsionalitas; Asas Profesionalitas; dan Asas Akuntabilitas); Ketiga, UU No. 37 Tahun 2008 tentang Ombudsman Republik Indonesia (terdapat delapan asas yaitu: kepatutan; keadilan; non-diskriminasi; tidak memihak; akuntabilitas; keseimbangan; keterbukaan; dan kerahasiaan); Keempat, UU No. 5 Tahun 2014 tentang Aparatur Sipil Negara (terdapat tiga belas asas yaitu : kepastian hukum; profesionalitas; proporsionalitas; keterpaduan; delegasi; netralitas; akuntabilitas; efektif dan efisien; keterbukaan; nondiskriminatif; persatuan dan kesatuan; keadilan dan kesetaraan; dan kesejahteraan); Kelima, UU No. 25 Tahun 2009 tentang Pelayanan Publik (terdapat dua belas asas, yaitu: kepentingan umum; kepastian hukum; kesamaan hak; keseimbangan hak dan kewajiban; keprofesionalan; partisipatif; persamaan perlakuan/tidak diskriminatif; keterbukaan; akuntabilitas; fasilitas dan perlakuan khusus bagi kelompok rentan; ketepatan waktu; dan kecepatan, kemudahan, dan keterjangkauan); Keenam, UU No. 23 Tahun 2014 tentang Pemerintah Daerah (terdapat sepuluh asas, yaitu: kepastian hukum; tertib penyelenggara negara; kepentingan umum; keterbukaan; proporsionalitas; profesionalitas; akuntabilitas; efisiensi; efektifitas; dan keadilan); dan Ketujuh, UU No. 30 Tahun 2014 tentang Administrasi Pemerintahan (terdapat delapan asas, yaitu: kepastian hukum; kemanfaatan; ketidakberpihakan; kecermatan; tidak 
menyalahgunakan kewenangan; keterbukaan; kepentingan umum; dan pelayanan yang baik).

Selain hal di atas, terdapat AUPB dalam yurisprudensi, yaitu asas kepastian hukum, asas kecermatan, asas tidak menyalahgunakan wewenang, asas tertib penyelenggaraan pemerintahan. ${ }^{49}$ Berdasar telaah tujuh UU, doktrin hukum, dan yurisprudensi perkara TUN, dapat disimpulkan:

(i) Kedudukan AUPB sebagai norma hukum positif telah menempatkan AUPB sebagai asas yang mengikat kuat; (ii) AUPB sebagian besar telah menjadi norma hukum tertulis dan sebagian lainnya merupakan prinsip yang tidak tertulis; (iii) AUPB telah memiliki kedudukan sebagai dasar atau alasan bagi Penggugat untuk mendalilkan gugatan dalam perkara TUN di pengadilan; (iv) AUPB merupakan alat uji bagi hakim TUN untuk menguji keabsahan atau pembatalan sebuah Keputusan TUN, sehingga, konsekuensinya, pelanggaran terhadap AUPB dapat disebutkan secara tegas oleh hakim dalam amar putusan; (v) AUPB dapat dijadikan dasar bagi hakim dalam memaknai kekaburan hukum di bidang Hukum Administrasi Negara, asalkan didasarkan pada pertimbanganpertimbangan yang tepat dan akurat, dengan indikator indikator yang jelas, serta didukung oleh fakta-fakta hukum yang terungkap di persidangan..$^{50}$

AUPB sebagai asas memiliki peran ganda untuk bersentuhan dengan sistem hukum positif menjadi kaidah penilaian sebagai tolok ukur (waarderingsnormen). Asas hukum mengungkapkan nilai mengenai sistem hukum karena berfungsi sebagai kaidah penilaian, tetapi asas hukum hanya sebagian saja yang dapat direalisasikan dalam hukum positif. Sejauh nilai suatu asas hukum itu diwujudkan dalam kaidah hukum dari sistem hukum positif, maka asas hukum itu berada di dalam sistem tersebut. ${ }^{11}$ Sebagai kaidah penilaian, asas hukum dapat mewujudkan kaidah hukum tertinggi dari suatu sistem hukum positif. Itu sebabnya asas hukum merupakan dan berfungsi sebagai fondasi dari sistem hukum. Asas hukum sifatnya terlalu umum untuk dapat berperan sebagai pedoman langsung bagi perbuatan tidak seperti aturan-aturan hukum, karena itu asas hukum harus dikonkretisasikan. ${ }^{52}$

\footnotetext{
${ }^{49}$ Cekli S. Pratiwi dkk, Penjelasan Hukum Asas asas Umum Pemerintahan Yang Baik. Hukum Administrasi Negara, Mahkamah Agung Republik Indonesia, Jakarta, 2016, hlm. 16.

${ }^{50}$ Ibid., hlm. 16.

51 Arief Sidharta, Refleksi Tentang Hukum, Aditya Bakti, Bandung, 1995, hlm. 122.

52 Sudikno Mertokusumo, Mengenal Hukum Suatu Pengantar, Liberty, Yogyakarta, 2003, hlm. 62.
} 
Filtrasi terhadap AUPB memerlukan Pancasila dalam dinamika normatif tepatnya dalam Pembukaan UUD RI 1945. Dalam rangka memajukan kesejahteraan umum, perlu berdasar kepada Ketuhanan Yang Maha Esa, Kemanusiaan yang adil dan beradab, Persatuan Indonesia, Kerakyatan yang dipimpin oleh hikmat kebijaksanaan dalam Permusyawaratan/Perwakilan, serta dengan mewujudkan suatu Keadilan sosial bagi seluruh rakyat Indonesia. Mochtar Kusumaatmadja, menegaskan perlu dipertahankan asas-asas Pancasila sebagai berikut:

(i) Asas kesatuan dan persatuan atau kebangsaan mengamanatkan bahwa hukum Indonesia harus merupakan hukum nasional yang berlaku bagi seluruh bangsa Indonesia; (ii) Asas Ketuhanan mengamanatkan bahwa tidak boleh ada produk hukum nasional yang bertentangan dengan agama yang bersifat menolak atau bermusuhan dengan agama; (iii) Asas demokrasi mengamanatkan bahwa dalam hubungan hukum dengan kekuasaan, kekuasaan harus tunduk pada hukum, kekuasaan ada pada rakyat dan wakilwakil rakyat; (iv) Asas keadilan sosial mengamanatkan bahwa semua warga negara mempunyai hak yang sama dan bahwa semua orang sama di depan hukum. ${ }^{53}$

Terdapat asas equity dalam mewujudkan keadilan sosial bersandar pada nilainilai atau falsafah Pancasila. Sjachran Basah menegaskan, harus adanya suatu jaminan bahwa tindakan-tindakan pemerintah tidak boleh melanggar hak asasi manusia serta adanya suatu keseimbangan antara kepentingan negara yang mewakili kepentingan umum dan perorangan. ${ }^{44}$ Selaras dengan teori hukum integratif, yang menempatkan Pancasila sebagai pusat atau ruang tengah terhadap pembangunan hukum Indonesia. Romli Atmasasmita, menegaskan bahwa perkembangan teori hukum Indonesia saat ini menghasilkan tripartite character of social and bureaucratic enginering, yaitu perpaduan sistem norma dinamis, sistem perilaku dan sistem nilai yang bersumber pada Pancasila sebagai filsafat kehidupan bangsa Indonesia. ${ }^{55}$

Teori hukum integratif mempunyai peranan penting dalam mendefinisikan dan mempertahankan nilai-nilai dan idealisme yang dapat memelihara

${ }^{53}$ Mochtar Kusumaatmaja, Konsep-Konsep Hukum dalam Pembangunan, Alumni, Bandung, 2006, hlm. 48.

54 Sjachran Basah, Op. Cit., hlm. 3.

55 Romli Atmasasmita, Teori Hukum Integratif : Rekonstruksi Terbadap Teori Hukum Pembangunan dan Teori Hukum Progresif, Genta Publishing, Yogyakarta, 2012, hlm. 2-3. 
kesinambungan pandangan hidup Pancasila.56 Pancasila ditempatkan sebagai pusat dan sumber dari sistem nilai, sistem perilaku yang diadopsi dalam kesatuan norma dinamis. Pancasila merupakan sistem nilai yang sangat mengedepankan asas equity dalam mengoreksi perwujudan asas keadilan sehingga memberi landasan hukum bagi tindakan diskresi pemerintah. ${ }^{57}$ Ditinjau dari klasifikasi AUPB di dalam tujuh peraturan perundang-undangan, yurisprudensi, dengan alat teori hukum integratif dalam meletakkan Pancasila sebagai pusat dari sistem nilai dan sistem perilaku, penulis melakukan konstruksi AUPB sebagai dasar penggunaan diskresi sebagai berikut:

a. Asas Ketuhanan

Sila Ketuhanan dan Sila Kemanusiaan menjadi based morality of nation. Etika bersama dengan misi profetik agama harus dibawa ke dalam kehidupan publik agar memberikan kontribusi besar bagi penciptaan budaya demokrasi dan kemajuan kebangkitan serta kemerdekaan bangsa. ${ }^{8}$ Output yang dihasilkan adalah eksistensi nilai etik sebagai panduan bernegara. Diskresi diharapkan mempunyai tanggung gugat moralitas dan dapat dipertanggungjawabkan dalam pribadi penggunanya kepada Tuhan. Sehingga menciptakan penggunaan Diskresi berfilosofis religius dan profetik.

b. Asas Moralitas

Pancasila sebagai meta-norm atau sumber dari segala sumber hukum adalah refleksi dari nilai luhur bangsa Indonesia, termasuk moral. Hukum tidaklah otonom, hukum tidak dapat berdiri mandiri tanpa adanya pengaruh/anasir diluar hukum, seperti faktor ekonomi, politik, sosial dan budaya bahkan moralitas. Parsons menempatkan hukum sebagai salah satu sub-sistem dalam sistem sosial yang lebih besar. ${ }^{59}$ Diskresi ditempatkan sebagai validitas yang sejalan dengan moral. Moral menjadi koridor penuntun diskresi yang diimplementasikan oleh pengguna diskresi. Selaras dengan hakikat moral sebagai penuntun manusia dalam setiap kegiatan hidupnya. Aristoteles

${ }^{56}$ Ibid., hlm. 3.

${ }^{57}$ Krishna D. Darumurti, Op. Cit., hlm. 90.

${ }^{58}$ Yudi Latif, Negara Paripurna, Historisitas, Rasionalitas, dan Aktualitas Pancasila, Gramedia Pustaka Utama, Jakarta, 2012, hlm. 120.

${ }_{59}$ Bernard L. Tanya dkk, Op. Cit., hlm. 139. 
menjabarkan inti manusia adalah moral yang rasional, yang memandang kebenaran (theoria, kontemplasi) sebagai keutamaan hidup (summum bonum), manusia dipandu akal dan moral. ${ }^{60}$ Diskresi diharapkan menginterpretasikan keterbukaan, kejujuran serta kepatutan, selaras dengan sila Ketuhanan dan sila Kemanusiaan sebagai based morality of nation.

c. Asas Kepastian Hukum Yang adil

Negara hukum adalah suatu konsep yang bukan hanya harus dipahami, tetapi juga harus dipraktekkan dan dijalankan. ${ }^{61}$ Oleh karenanya, dalam mengilhami konsep negara hukum harus dipandang sebagai mekanisme kontrol bukan hanya dalam mewujudkan suatu kepastian hukum, namun disini negara hadir untuk menjamin juga kepentingan masyarakatnya. Keadilan banyak disuarakan oleh aliran etis yang menganggap pada asasnya tujuan hukum adalah sematamata untuk mencapai suatu keadilan. Menurut Achmad Ali keadilan adalah hal yang abstrak, keadilan bagaimanapun menyangkut nilai-etis yang dianut oleh seseorang. ${ }^{62}$ Penggunaan diskresi harus memenuhi rasa keadilan bagi rakyat.

d. Asas Kemanfaatan

Manusia diciptakan oleh Tuhan dengan seperangkat hak untuk menjamin derajatnya sebagai manusia yang terangkum dalam HAM. Negara hukum (rechtstaat) diakui sebagai kerangka pengatur untuk menjamin hak asasi manusia berupa kepentingan keadilan bagi semua orang. Setiap orang berhak mendapatkan hak keadilannya. Dengan demikian, negara hukum yang dikembangkan bukanlah absolute rechtsstaat melainkan democratische rechtsstaat. 63 Diskresi diharapkan mampu membuka ruang untuk menyelesaikan persoalan mendesak dalam masyarakat dengan tetap menjunjung tinggi HAM sebagai bentuk pengakuan terhadap harkat dan martabat manusia dalam lingkup Kemanusiaan yang Adil dan Beradab.

e. Asas Kesamaan

${ }^{60}$ Bernard L. Tanya, Penegakkan Hukum Dalam Terang Etika, Genta Publishing, Yogyakarta, 2011, hlm. 103.

${ }^{61}$ Yovita A. Mangesti, Bernard L. Tanya, Moralitas Hukum, Genta Publishing, Yogyakarta, hlm. 86.

62 Achmad Ali, Op. Cit., hlm. 85.

${ }^{63}$ Mohamad Sinal, Pancasila Konsesnsus Bangsa-Bangsa Indonesia, Madani, Malang, 2017, hlm. 104. 
Sejatinya, wewenang pemerintah berasal dari kedaulatan rakyat yang telah dimandatkan dalam bentuk kontrak sosial antara rakyat dengan negara. Menurut Nor Hadi, teori kontrak sosial muncul karena adanya interelasi dalam kehidupan sosial masyarakat, agar terjadi keselarasan, keserasian, dan keseimbangan, termasuk dalam lingkungan. Keseimbangan (equality), diwujudkan dengan kontrak sosial secara tersusun ataupun secara tersurat maupun tersirat, sehingga terjadi kesepakatan-kesepakatan yang saling melindungi kepentingan masing-masing.64 Pasal 28 D ayat (1) UUD RI 1945 menegaskan prinsip persamaan dalam bentuk perlakuan yang sama di hadapan hukum. Dengan asas ini, diharapkan diskresi dapat seimbang, tidak memihak, tidak diskriminatif serta terbuka bagi masyarakat. Sebagai falsafah negara yang menjiwai konstitusi, Pancasila merupakan testamen historis yang membela prinsip kesamaan. Prinsip kesamaan dan kesederajatan dalam hubungan antar manusia yang dijiwai oleh sila Kemanusiaan. ${ }^{65}$

f. Asas Kecermatan

Asas kecermatan ditujukan untuk menggunakan diskresi secara cermat. Penulis membagi kecermatan tersebut menjadi dua : Pertama, kecermatan membaca keadaan sebelum menggunakan diskresi, termasuk memahami konsekuensi serta akibat penggunaannya; Kedua, kecermatan dalam proses penggunaan diskresi, yaitu tata cara, bentuk, serta formulasinya harus mengedepankan kepentingan umum, tidak menimbulkan konflik kepentingan, tidak menerabas kuasa perjanjian perdata. Diharapkan asas kecermatan menjadi sarana kontrol pengguna diskresi, mendorong terciptanya diskresi yang sesuai dengan tujuannya serta mampu dipertanggungjawabkan kepada masyarakat.

g. Asas Kesejahteraan

Indonesia adalah negara demokratis yang menganut "Negara Kesejahteraan" (walvaarstaat) bukan "Negara Penjaga Malam" (nachtwachterstaat). Terkait konsepsi pilihan negara kesejahteraan Indonesia ini, Moh. Hatta menggunakan

64 Murzully Nur, Denies Priantinah, "Analisis Faktor-Faktor Yang Mempengaruhi Pengungkapan Corporate Social Responsibility di Indonesia (Studi Empiris Pada Perusahaan Berkategori High Profile yang Listing di Bursa Efek Indonesia)", Jurnal Nominal, Vol. 1 No. 1, 2012.

65 Yudi Latif, Op. Cit., hlm. 239-240. 
istilah "Negara Pengurus". 66 Dalam paradigma ini, diskresi harus berpedoman terhadap kepentingan umum. Refleksi Pancasila dalam Pembukaan UUD RI 1945 dan tujuan "memajukan kesejahteraan umum" dianggap sebagai kausa negara kesejahteraan, mendeskripsikan kewajiban pemerintah dalam mencapai kesejahteraan berupa Keadilan Sosial Bagi Seluruh Rakyat Indonesia. Diskresi harus sejalan dengan pengkonkritisasian nilai ini, sehingga mampu menjadi sarana ringkas dan ideal pemerintah untuk mengatasi permasalahan dalam mencapai tujuan negara tersebut.

h. Asas Ketaatan

Asas ketaatan menjadi kontrol terhadap penggunaan diskresi, agar tidak melampaui wewenang, mencampuradukkan wewenang, atau berbuat sewenang-wenang. Dalam Putusan MA RI No. 10 K/TUN/1992, Putusan MA RI No. 10 K/TUN/1992, Putusan MA RI No. 34 K/TUN/1992, dan Putusan MA RI No. 150 K/TUN/2001, Hakim Agung memberikan arahan bahwa Badan atau Pejabat Pemerintahan dalam menggunakan wewenangnya tidak boleh untuk tujuan lain, selain dari maksud diberikannya wewenang tersebut untuk menjaga keselarasan penggunaan wewenang dengan tujuan yang ingin dicapai. Penulis mengambil yurisprudensi ini dalam merumuskan asas ketaatan, berupa ketaatan pada wewenang dan batasan dari wewenang untuk menggunakan diskresi.

i. Asas Pertanggungjawaban

Asas pertanggungjawaban mengedepankan prinsip profesionalitas dan akuntabilitas. Profesionalitas berarti penggunaan diskresi harus sesuai dengan wewenang, tidak melampaui wewenang, tidak mencampuradukkan wewenang dan bukan merupakan perbuatan sewenang-wenang. Diskresi harus melalui tahapan yang jelas dan rasional, dalam hal penyebab penggunaannya, maupun memahami konsekuensinya. Diskresi harus akuntabel dapat dipertanggungjawabakan penggunaannya kepada negara dan masyarakat. Dalam asas ini harus dipenuhi bentuk perlindungan hukum terhadap administratur negara, karena dalam struktur puncak administrasi, dipimpin

${ }^{66}$ Moh. Yamin, Naskah Persiapan UUD 1945: Risalab Sidang BPUPKI/PPKI, Sekretariat Negara RI, Jakarta, 1959, hlm. 299. 
oleh pejabat-pejabat yang terpilih melalui mekanisme politik sehingga menimbulkan pusaran arus politik yang menyeret birokrat political will dalam eksekusi kebijakan administratif.

\section{Penutup}

Kesimpulan dari penelitian ini adalah pertama, bentuk pembatasan diskresi termasuk persetujuan atasan pejabat pengguna diskresi berlawanan dengan hak pemerintah menggunakan kebebasan bertindak untuk menyelesaikan permasalahan konkret dan mendesak dalam masyarakat. Pengujian diskresi akibat hukumnya ditentukan secara prosedural dan wetmatigheid, berlawanan dengan diskresi harus terlebih dahulu dibuktikan secara doelmatigheid karena merupakan kebijaksanaan. Dalam ranah praktik, penyalahgunaan wewenang dalam diskresi langsung diabsorsi ke hukum pidana, seharusnya penyalahgunaan wewenang dalam diskresi menggunakan penyelesaian kaidah hukum administratif terlebih dahulu. Selain itu, perbedaan kaidah administrasi antara Indonesia dengan Jerman dengan ditempatkannya administrasi sebagai pilar keempat disamping eksekutif, legislatif dan yudikatif termasuk memberikan imunitas ke pengguna diskresi.

Kedua, merumuskan AUPB sebagai dasar diskresi yang berlandaskan Pancasila, perlu langkah : Pertama, melakukan filtrasi atau penyaringan terhadap AUPB yang eksis dalam peraturan perundang-undangan, doktrin dan yurisprudensi, dan Kedua, membangun konstruksi undang-undang dengan AUPB yang telah difiltrasi tersebut sehingga sesuai dengan Pancasila sebagai dasar penggunaan diskresi, hasilnya merumuskan asas Ketuhanan, asas moralitas, asas kepastian hukum yang adil, asas kemanfaatan, asas kesamaan, asas kecermatan, asas kesejahteraan, asas ketaatan, dan asas pertanggungjawaban.

Saran dalam penelitian ini adalah : Pertama, dalam tataran praktis, pengguna Diskresi menggali makna ermessen dan konsekuensinya, mempertimbangkan berbagai antinomi yang ditemukan dalam UU No. 30 Tahun 2014, Kedua, dalam tataran yuridis, menghimbau kepada legislator mengundangkan pengaturan mengenai diskresi dalam bentuk undang-undang tersendiri.

\section{Daftar Pustaka}




\section{Buku}

Ali, Achmad, Menguak Tabir Hukum, Chandra Pratama, Jakarta, 1996.

Atmasasmita, Romli, Teori Hukum Integratif : Rekonstruksi Terhadap Teori Hukum Pembangunan dan Teori Hukum Progresif, Genta Publishing, Yogyakarta, 2012.

Basah, Sjachran, Eksistensi dan Tolok Ukur Badan Peradilan Administrasi di Indonesia, Alumni, Bandung, 1985.

, Perlindungan Hukum terhadap Sikap-Tindak Administrasi Negara, Alumni, Bandung, 1992.

Cotterrell, Roger, The Sociology Of Law : An Introduction, Butterworths / Oxford University Press, London, 1992.

Darumurti, Krishna D, Diskresi Kajian Teori Hukum, Genta Publishing, Yogyakarta, 2016.

F. Susanto, Anthon, Penelitian Hukum Transformatif-Partisipatoris, Setara Press, Malang, 2015.

Friedmann, W, Teori dan Filsafat Hukum, Telaah Kritis Atas Teori-Teori Hukum, Rajawali Press, Jakarta, 1990.

Huda, Ni'matul, Hukum Tata Negara Indonesia, Rajawali Press, Jakarta, 2005.

Indroharto, Peradilan Tata Usaha Negara, Pustaka Sinar Harapan, Jakarta, 1993.

Islamy, Irfan, Prinsip-Prinsip Perumusan Kebijakan Negara, Bina Aksara, Jakarta, 2004.

Kusumaatmaja, Mochtar, Konsep-Konsep Hukum dalam Pembangunan, Alumni, Bandung, 2006.

L. Tanya, Bernard dkk, Teori Hukum Strategi Tertib Manusia Lintas Ruang dan Generasi, Genta Publishing, Yogyakarta, 2010.

, Penegakkan Hukum Dalam Terang Etika, Genta Publishing, Yogyakarta, 2011.

Latif, Yudi, Negara Paripurna, Historisitas, Rasionalitas, dan Aktualitas Pancasila, Gramedia Pustaka Utama, Jakarta, 2012.

M. Hadjon, Phillipus dkk, Hukum Administrasi dan Good Governance, Universitas Trisakti, Jakarta, 2010.

M. Marzuki, Peter, Penelitian Hukum, Prenadamedia Group, Jakarta, 2005.

Manan, Bagir, Konvensi Ketatanegaraan, CV Armico, Bandung, 1987.

Mangesti, Yovita. A dan Bernard L. Tanya, Moralitas Hukum, Genta Publishing, Yogyakarta, 2014.

Mappiasse, Syarif, Logika Hukum Pertimbangan Putusan Hakim, Predana Media Group, Jakarta, 2015. 
Mertokusumo, Sudikno, Mengenal Hukum Suatu Pengantar, Liberty, Yogyakarta, 2003

Pratiwi, Cekli Setya dkk, Penjelasan Hukum Asas asas Umum Pemerintahan Yang Baik Hukum Administrasi Negara, Mahkamah Agung Republik Indonesia, Jakarta, 2016.

Rahardjo, Satjipto, Ilmu Hukum, Alumni, Bandung, 1986.

Sidharta, Arief, Refleksi Tentang Hukum, Aditya Bakti, Bandung, 1995.

Sinal, Mohamad, Pancasila Konsesnsus Bangsa-Bangsa Indonesia, Madani, Malang, 2017.

Siswanto, Joko, Pancasila Refleksi Komperhensif Hal-Ihwal Pancasila, Ladang Kata, Yogyakarta, 2015.

Sirajudin, dkk, Hukum Pelayanan Publik Berbasis Partisipasi Dan Keterbukaan Informasi, Setara Press, Malang, 2012.

Winarno, Pendidikan Pancasila di Perguruan Tinggi (Panduan Praktis Pembelajaran), Yuma Pustaka, Surakarta, 2012.

Yamin, M, Naskah Persiapan UUD 1945: Risalah Sidang BPUPKI/PPKI, Sekretariat Negara RI, Jakarta, 1959.

\section{Jurnal}

A.Mochtar, Zainal, "Antinomi dalam Peraturan Perundang-Undangan di Indonesia", Hasanuddin Law Review, Vol.1 No. 3, Desember 2015.

Endang, M. Ikbar Andi, “Diskresi Dan Tanggungjawab Pejabat Pemerintahan Menurut Undang-Undang Administrasi Pemerintahan", Jurnal Hukum Peratun, Vol. 1 No. 2, Agustus 2018.

Juansah, Jajang, "Peningkatan Mutu sari Buah Nanas Dengan Memanfaatkan Sistem Filtrasi Aliran Dead-End Dari Membran Selulosa Asetat", Makara Sains, Vol. 13 No.1, April 2009.

M. Hadjon, Philipus, "Peradilan Tata Usaha Negara Dalam Konteks UndangUndang No. 30 TH 2014 Tentang Administrasi pemerintahan", Jurnal Hukum Dan Peradilan, Vol. 4 No. 1, Maret 2015, hlm. 51-64.

Mustamu, Julista, "Diskresi Dan Tanggungjawab Administrasi Pemerintahan", Jurnal Sasi, Vol. 17 No. 2, April-Juni 2011.

Nur, Marzully dan Denies Priantinah, "Analisis Faktor-Faktor Yang Mempengaruhi Pengungkapan Corporate Social Responsibility di Indonesia (Studi Empiris Pada Perusahaan Berkategori High Profile yang Listing di Bursa Efek Indonesia)", Jurnal Nominal, Vol. 1 No. 1, 2012.

Permana, Tri Cahya Indra, "Peradilan Tata Usaha Negara Pasca Undang-Undang Administrasi Pemerintahan Ditinjau Dari Segi Access To Justice", Jurnal Hukum dan Peradilan, Vol. 4 No. 3, November 2015. 
Prasojo, Eko, "(Rancangan) Undang-Undang Administrasi Pemerintahan untuk Pembangunan Hukum Administrasi Negara dan Penciptaan Good Governance" disampaikan pada Bimbingan Teknis Hakim PTUN, Jakarta, 31 Maret-2 April 2011.

Rusnan, "Konsep Negara Hukum Dalam Hubungan Kekuasaan Freiss Ermessen Dalam Welfare State", Jurnal IUS, Vol. 11 No. 4, April 2014.

Suandi, I Wayan, “Eksistensi Kebijakan Publik Dan Dalam Penyekenggaraan Pemerintahan Daerah", Jurnal Ilmiah Fisip, Vol. 1, 2010.

\section{Peraturan Perundang-Undangan}

Undang-Undang Dasar Negara Republik Indonesia Tahun 1945

Undang-Undang Nomor 30 Tahun 2014 tentang Administrasi Pemerintahan; Tambahan Lembaran Negara Republik Indonesia Nomor 5601

\section{Website :}

“Jokowi Minta Kebijakan Jangan Dipidana", http://m.republika.co.id/berita/ koran/halaman-1/15/08/25/ntmkg612 jokowi-minta-kebijakan jangandipidana, diakses pada hari Sabtu, tanggal 3 Agustus 2018.

"KPK : Pejabat Jangan Takut Terbitkan Diskresi" https://m.cnnindonesia.com, diakses Kamis 29 Agustus 2019 pukul 19.00 WIB.

\section{Putusan Pengadilan :}

Putusan Mahkamah Agung Nomor 977 K/PID/2004. 